\title{
Seasonal changes in glucocorticoid and testosterone concentrations in free-living arctic ground squirrels from the boreal forest of the Yukon
}

\author{
Rudy Boonstra, Anne H. Hubbs, Eileen A. Lacey, and Carolyn J. McColl
}

\begin{abstract}
We examined how glucocorticoid and testosterone concentrations changed from spring to summer by livetrapping free-living populations of arctic ground squirrels (Spermophilus parryii). The primary glucocorticoid was found to be cortisol, with corticosterone below measurable concentrations in most individuals. Livetrapping elicited a strong stress response in both sexes: breeding males and females trapped in spring had free cortisol concentrations 4 and 34 times, respectively, those of base-line animals. The maximum corticosteroid-binding capacity (MCBC) was unaffected by trapping and was about 3 times higher in breeding females than in breeding males. Over the active season, MCBC values were lowest in all male classes (juveniles, nonreproductive adults, and reproductive adults), being less than half those in all female classes; pregnant females had values approximately twice those of juvenile females. However, free cortisol concentrations were similar in all female classes and in juvenile males and about half those in adult males. Livetrapping increased testosterone concentrations in males over those found in samples from base-line males, and testosterone concentrations did not affect MCBC values. Testosterone concentrations in livetrapped animals differed significantly among male classes, with nonreproductive males maintaining concentrations $64 \%$ of those in breeding males and 10 times those in juveniles.
\end{abstract}

Résumé : Nous avons examiné les variations des concentrations de glucocorticoïdes et de testostérone du printemps à l'été par piégeage d'animaux vivants dans des populations de Spermophiles arctiques (Spermophilus parryii) en nature. Le principal glucocorticoïde est le cortisol; la corticostérone est présente en quantité trop faible pour être décelée chez la plupart des individus. Le piégeage déclenche une forte réaction de stress chez les deux sexes; chez les individus reproducteurs, mâles et femelles, au printemps les animaux piégés avaient des concentrations de cortisol 4 et 34 fois plus élevées respectivement que les valeurs de base. La capacité maximale de liaison des corticostéroïdes (MCBC) n'a pas été affectée par le piégeage et était environ 3 fois plus élevée chez les femelles reproductrices que chez les mâles. Pendant la saison d'activité, les valeurs de MCBC étaient plus faibles chez les mâles de toutes les classes (juvéniles, adultes non reproducteurs et adultes reproducteurs), et équivalaient à la moitié de celles des femelles de toutes les classes d'âge et les femelles enceintes avaient des valeurs environ deux fois plus élevées que celles des femelles juvéniles. Cependant, les concentrations de cortisol libre étaient semblables chez toutes les classes de femelles et chez les mâles juvéniles et équivalaient à environ la moitié de celles des mâles adultes. Le piégeage a entraîné une augmentation des concentrations de testostérone chez les mâles par rapport aux concentrations de base et les concentrations de testostérone n'ont pas affecté les valeurs de MCBC. Les concentrations de testostérone chez les animaux capturés vivants différaient significativement d'une classe à l'autre chez les mâles et les mâles non reproducteurs avaient des concentrations équivalentes à $64 \%$ de celles rencontrées chez les reproducteurs et à 10 fois celles des juvéniles.

[Traduit par la Rédaction]

\section{Introduction}

A critical physiological system that allows animals to cope with rapid yearly changes in biological activities (e.g., breed-

Received May 30, 2000. Accepted September 25, 2000.

Published on the NRC Research Press website on December 21, 2000.

R. Boonstra, ${ }^{1}$ A.H. Hubbs, and C.J. McColl. Division of Life Sciences, University of Toronto at Scarborough, 1265 Military Trail, Scarborough, ON M1C 1A4, Canada. E.A. Lacey. Museum of Vertebrate Zoology, University of California, Berkeley, CA 94720, U.S.A.

${ }^{1}$ Author to whom all correspondence should be addressed (e-mail: boonstra@scar.utoronto.ca). ing, foraging, and dispersal) and to respond adaptively to potentially harmful environmental challenges (e.g., conspecific aggression and predator attack) is the hypothalamic-pituitaryadrenocortical (HPA) feedback system (Sapolsky 1992). Glucocorticoids produced by the adrenal glands play two major physiological roles: first, they are critical in normal day to day activities associated with the diurnal cycle of waking, such as increased locomotion, exploratory behaviour, appetite, and food-seeking behaviour (McEwen et al. 1988); second, they play a central role in allowing animals to adapt to short-term stressors through stimulation of hepatic gluconeogenesis, inhibition of glucose uptake by peripheral tissues, suppression of inflammatory responses, suppression of immune responses, and inhibition of the secretion of several hormones and neuropeptides (Munck et al. 1984). 
Reproduction has a major impact on glucocorticoid concentration in mammals, particularly females (Challis et al. 1977; Martin et al. 1977; Liggins 1982; Boonstra and Boag 1992). Pregnancy and lactation cause a major increase in concentrations of corticosteroid and corticosteroid-binding globulin (the blood carrier protein for glucocorticoids) in a variety of rodent species (Rosenthal et al. 1969a, 1969b; McDonald et al. 1988), and prenatal and postnatal maternal stresses may affect offspring fitness (e.g., Dahlof et al. 1977; Herrenkohl 1979; Crump and Chevins 1989; Sachser and Kaiser 1996). Reproduction is particularly stressful, especially for males, often being associated with intense intrasexual competition, and in some species, with pronounced negative effects on survival. The most extreme example of this is found in the males of some of the dasyurid marsupials, in which breeding is associated with high free corticosterone concentrations, and is followed by complete male mortality as the HPA feedback system becomes dysfunctional (Bradley et al. 1980; McDonald et al. 1981; Bradley 1987). Lee and Cockburn (1985) argued that this breeding-induced stress response is adaptive in that it ultimately promotes reproductive fitness. Boonstra and Boag (1992) proposed that similar adaptive stress responses may occur in mammals which have life histories similar to those of the dasyurids (i.e., one intense breeding opportunity per year and low between-year survival rates). Many ground squirrel species show some of these patterns. Male ground squirrels typically emerge from hibernation earlier, move widely in search of females, are heavier, sustain more injuries, lose more mass, and sustain higher mortality rates, particularly after breeding, than adult females (Morton and Sherman 1978; Michener and Locklear 1990).

The arctic ground squirrel (Spermophilus parryii) is the largest ground squirrel species in North America, living primarily in the arctic tundra of Canada and Alaska and, in the northwest, also in the boreal forest. Its active life is compressed into the 3-5 months of the brief northern summer, with hibernation through the severe northern winter occupying the rest of its biological year. The seasonal sequences of changes in glucocorticoid concentration in both sexes and testosterone concentration in males are poorly understood in ground squirrels, and our primary objective is to document these changes, focusing on the period during and just after reproduction until midsummer. Our secondary objective is to assess whether the ground squirrels are stressed by the challenge of livetrapping and handling.

\section{Methods and materials}

\section{Study species}

To understand the sequence of changes in hormone concentrations during the active season of arctic ground squirrels, it is necessary to appreciate the yearly activity and reproductive cycle in the southern Yukon (Lacey 1991; Hubbs and Boonstra 1997; Karels et al. 2000). Adult males emerge from hibernation in early to midApril and adult females approximately 1 week later. Mating takes place within 3-4 days of female emergence, gestation lasts 25 days, and young appear above ground 27 days after birth. Nonreproductive adult males disperse after the young emerge. Juvenile females tend to remain near the natal burrow, whereas juvenile males usually disperse 4 weeks after emergence (Byrom and Krebs 1999). Adult females usually enter hibernation between late July and mid-August, adult males shortly thereafter, and juveniles as late as in September or early October.

\section{Study area}

The study was conducted at two sites in southwestern Yukon. The first site was in the Kluane Game Sanctuary $\left(60^{\circ} 47^{\prime} \mathrm{N}\right.$, $137^{\circ} 40^{\prime} \mathrm{W}$ ) on Bear Creek Flats at the north end of the Alsek River valley (Lacey 1991). Ground squirrels live in open meadows surrounded by dense stands of willow, white spruce, and aspen poplar. This population was studied intensively during the summers of 1987-1990; it had previously had been studied by McLean (1981) during the summers of 1977-1979. The second site was approximately $50 \mathrm{~km}$ west of the first site along the Alaska Highway in the Shakwak Trench east of Kluane Lake $\left(61^{\circ} \mathrm{N}, 138^{\circ} \mathrm{W}\right)$. Ground squirrels lived primarily in open spruce forest, but were also found in meadows and road side verges. This was the site of a 10-year study into the ecosystem dynamics of the boreal forest (Boutin et al. 1995; Krebs et al. 1995). A description of the site and of arctic ground squirrel demography can be found in Hubbs and Boonstra (1997), Byrom et al. (2000), and Karels et al. (2000).

\section{Livetrapping technique}

The trapping technique was similar at both sites. Tomahawk live traps $(14 \times 14 \times 41$ or $15 \times 15 \times 48 \mathrm{~cm}$; Tomahawk Live Trap Co., Tomahawk, Wisconsin, U.S.A.) baited with peanut butter were set outside burrow entrances between 7:30 and 8:30 a.m. and checked as indicated below. All new squirrels were restrained in a net bag and tagged in both ears (Monel No. 1, National Band and Tag Company), and on each capture, tag number, location, body mass ( $\pm 5 \mathrm{~g}$ with Pesola scales), sex, and breeding condition (testes scrotal or abdominal for males; pregnant, lactating, or nonreproductive for females) were recorded. Males were classified as reproductive adults if their testes were descended and their scrotum was darkly pigmented with the surrounding hair bleached, as nonreproductive adults if their testes were abdominal and their scrotum pinkish in colour with the surrounding hair not bleached, and as juveniles if they were born in the spring of that year. Though most of the adult males classified as nonreproductive probably had bred (both yearlings and >2-year-olds breed in April-May), $8 \%$ of overwintering yearling males in our populations fail to mature in spring $(N=52$; T.J. Karels, personal communication) and remain at their natal burrow (Lacey 1991). Because of the rapid growth of all males subsequent to the mating period (T.J. Karels, personal communication) and because of the dispersal patterns of overwintering males (nonreproductive yearlings disperse from their natal site in June and males that have bred in spring disperse from their overwintering site from mid-June to July; Lacey 1991), we could not be certain whether adult males classified as nonreproductive in mid-June and July had been reproductive in spring. However, we detected no bimodality in hormone concentrations in nonreproductive adults. Trapping procedures and blood-collection procedures followed Canadian Council of Animal Care guidelines and were approved under a University of Toronto Animal Use Protocol for research based out of that university.

\section{Collection of blood samples}

At the Bear Creek Flats site, all members of the study population were livetrapped and individually tagged as part of a behavioural and ecological study (Lacey 1991). At first capture, a 0.5$\mathrm{mL}$ blood sample was collected from each individual via puncture of the suborbital sinus with a heparinized glass pipette (Lacey et al. 1997). Because traps were monitored closely, animals rarely remained in them for more than 20 min prior to the collection of blood samples; samples were collected within $5 \mathrm{~min}$ of removing an animal from a trap. Blood samples were centrifuged in the field within $15 \mathrm{~min}$ of collection and the serum and red cell portions were stored separately in liquid nitrogen $\left(-176^{\circ} \mathrm{C}\right)$ until they could 
be transferred to an ultracold freezer $\left(-70^{\circ} \mathrm{C}\right)$ at the University of Michigan. The samples were thawed once for allozyme analyses of paternity to be conducted (Lacey et al. 1997) and then refrozen. Frozen samples were shipped on dry ice to Toronto for hormone analyses and stored at $-70^{\circ} \mathrm{C}$ until analysis.

At the Kluane Lake site, $0.5-\mathrm{mL}$ plasma samples were collected from two groups of ground squirrels. A base-line group was collected between 26 April and 3 May 1991 and 4-6 May 1995 near the Alaska Highway after a gunshot (22 calibre) to the neck and bled within 2-3 min by heart puncture. Samples collected from these animals provided resting glucocorticoid (samples collected in 1991 only) and testosterone concentrations (samples from both 1991 and 1995). Samples were obtained from a group livetrapped (traps were checked at 1- to 1.5-h intervals) in the same area between 24 April and 8 May 1991 (Hubbs and Boonstra 1997) and bled via a suborbital sinus puncture with a heparinized glass pipette within $5 \mathrm{~min}$ of release from the trap. The blood was stored in heparinized tubes and centrifuged at the field laboratory. Plasma was stored at $-20^{\circ} \mathrm{C}$ prior to transport to the University of Toronto, where it was stored at $-70^{\circ} \mathrm{C}$ until analysis.

\section{Preliminary determination of glucocorticoid identity}

As sciurids appear to vary as to which adrenal glucocorticoid (cortisol or corticosterone) is the primary one secreted by the adrenal glands (see the Discussion), we assayed an initial plasma sample for both corticosterone and cortisol. For corticosterone, antibody B3-163 obtained from Endocrine Sciences (Tarzana, California) was used, as it is highly specific ( $0.4 \%$ cross-reaction to cortisol) using the corticosterone protocol given in Boonstra and Boag (1992). For cortisol (see the protocol below), antibody A-155 obtained from Western Chemical (Fort Collins, Colorado) (1.4\% cross-reaction to corticosterone) was used. The sample $(N=70)$ consisted mainly of males (68) caught in breeding condition $(N=38$, April to midMay) and nonbreeding condition throughout the rest of the summer $(N=30$, late May until mid-August).

\section{Cortisol assay}

We measured total plasma cortisol by the radioimmunoassay (RIA) method used by Boonstra and Singleton (1993), using anticortisol antibody A-155. Blank values for charcoal-stripped plasma and for solvent did not differ significantly from zero. All reagents were redistilled. The assay was sensitive to $10 \mathrm{pg} / 10 \mu \mathrm{L}$. The mean recovery of $\left[1,2,6,7-{ }^{3} \mathrm{H}\right]$ cortisol added to plasma was $105 \%$ ( $\mathrm{SE}=$ $1.2 \%$; range $100-107 \%$ ). The intra- and inter-assay coefficients of variation were 4 and $15 \%$, respectively. We calculated free cortisol concentrations using the method and constants given in Boonstra and McColl (2000).

Plasma corticosteroid-binding globulin (CBG) was measured for each sample as the maximum corticosteroid-binding capacity (MCBC) by the saturation ligand method described in McDonald et al. (1981), which we have used in a number of studies (e.g., Boonstra et al. 1998; Boonstra and McColl 2000). Briefly [1,2,6,7$\left.{ }^{3} \mathrm{H}\right]$ cortisol, diluted in nonradioactive cortisol to a known specific activity 5-20 times the expected capacity was added to $10 \mu \mathrm{L}$ plasma (analyzed in duplicate). We allowed for the contribution of the endogenous cortisol in the sample. The high-affinity fraction in the plasma, diluted in $0.5 \mathrm{~mL}$ phosphate buffer, was measured by liquid scintillation after separation from the free and albumin-bound fractions with dextran-coated charcoal at $4^{\circ} \mathrm{C}$ for $10 \mathrm{~min}$ (Tan and Mulrow 1975). The concentration of the high-affinity bound cortisol was then calculated, since the specific activity and the radioactivity of the bound fraction were known.

\section{Androgen assay}

Total plasma testosterone plus dihydrotestosterone was measured in duplicate by RIA using double diethyl ether extracts of plasma (for details see Boonstra and Singleton 1993; Boonstra and McColl
2000). The antibody (P43/11) was produced by Croze and Etches (1980) and showed a major cross-reaction with dihydrotestosterone (62\%) relative to testosterone. Blank values for charcoal-stripped plasma and for solvent did not differ significantly from zero. The assay was sensitive to $10 \mathrm{pg} / 25 \mu \mathrm{L}$ plasma. The mean recovery of $\left[1,2,6,7-{ }^{3} \mathrm{H}\right]$ testosterone (Amersham) added to plasma was $96.5 \%$ ( $\mathrm{SE}=0.7 \%$; range $92-102 \%)$. The intra- and inter-assay coefficients of variation were 5 and $6 \%$, respectively.

\section{Statistical and other analyses}

Data are expressed as means \pm SE. As recommended by Day and Quinn (1989), we used Cochran's test (Winer 1971) of homogeneity of variance. We found that the basic demographic data satisfied this criterion, hence we used no transformations. The hormone data for the ANOVA did not meet this criterion, however, and we used the $\log (x+1)$ transformation to make the variances homogeneous. All ANOVAs were performed using SuperANOVA (Gagnon et al. 1991). We used the Tukey-Kramer multiple-comparison post-hoc test to examine the significance of main effects.

In the Discussion we make comparisons with glucocorticoid concentrations in other sciurid species from the published literature. If the values were not included in the text or tables, we obtained them from the graphs. We were able to determine precise values from these graphs by scanning them with a scanner, saving them as a PICT file, and then reading the data points with the program DATATHIEF (a free program copyrighted by K. Huyser and J. van der Laan, Computer Systems Group, Nuclear Physics Section, National Institute for Nuclear Physics and High Energy Physics, Amsterdam, the Netherlands).

\section{Results}

\section{Primary glucocorticoid in arctic ground squirrels}

Corticosterone concentrations were low in all males, $8.05 \pm$ $1.63 \mathrm{ng} / \mathrm{mL}$, with zero concentrations recorded in 45 animals and $23.8 \pm 2.47 \mathrm{ng} / \mathrm{mL}$ in the rest; both females (bled in May 1991 and probably pregnant) had zero concentrations. Breeding condition (38 reproductive males and 30 nonreproductive males) did not affect whether males had nonzero concentrations $\left(\chi^{2}=0.006,1 \mathrm{df}, P=0.94\right)$. In contrast to the extremely low corticosterone concentrations in both males and females, cortisol concentrations in males were about 29 times higher $(230.59 \pm 12.83 \mathrm{ng} / \mathrm{mL}$; range $23.4-$ $568.5 \mathrm{ng} / \mathrm{mL}$ ) and both females had concentrations greater than $100 \mathrm{ng} / \mathrm{mL}$. Thus, we concluded that the principal adrenal glucocorticoid in arctic ground squirrels is cortisol, and in all subsequent RIA runs, we assayed only for it.

\section{Effects of capture and handling on plasma cortisol concentration}

To assess whether trapping and handling elicited a stress response in ground squirrels, we compared a sample from base-line animals with a sample from livetrapped animals from the Kluane Lake population that was collected in late April - early May (two-way ANOVA, sex versus treatment) (see Fig. 1 for sample sizes). All males were in breeding condition (testes scrotal). Though it is likely that most females had bred, since breeding occurs within 3 days of emergence and our collections were made near the end of the emergence period (Lacey 1991; Karels et al. 2000), we could not definitively assess pregnancy status (at least 5 of the baseline sample had small embryos), as they may have only recently bred. Livetrapping had no effect on MCBC values $\left(F_{[1,52]}=0.08, P=0.79\right)$. However, females had MCBC 
Fig. 1. Effect of trapping and handling on cortisol concentrations and maximum corticosteroid binding capacity (MCBC) (mean \pm SE) in arctic ground squirrels sampled in late April - early May 1991. Sample sizes for livetrapped and base-line (shot) animals were 19 and 8 males, respectively, and 20 and 9 females, respectively.
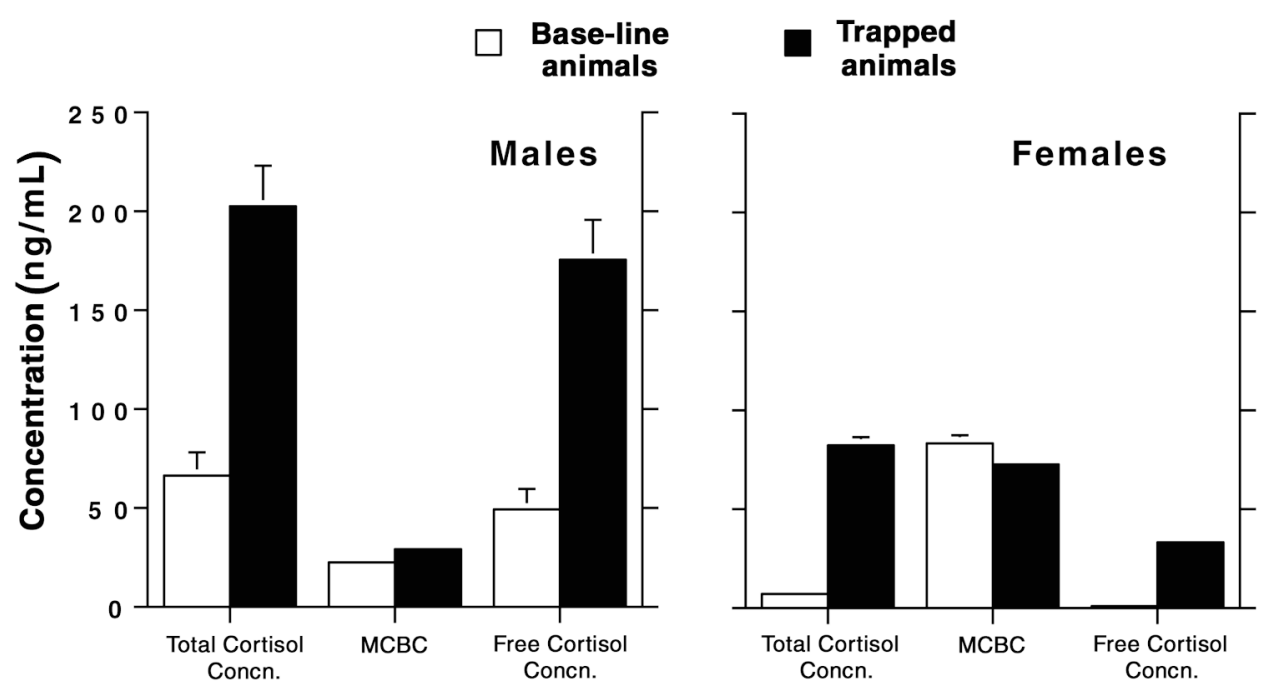

values 3-4 times higher than those of males $\left(F_{[1,52]}=136.3\right.$, $P<0.0001)$, and there was a suggestion of an interaction effect between sex and treatment $\left(F_{[1,52]}=3.6, P=0.06\right)$ (Fig. 1). Livetrapping resulted in a marked increase in both total cortisol and free cortisol concentrations relative to those in base-line animals $\left(F_{[1,52]}=145.2, P<0.0001\right.$, and $F_{[1,52]}=$ 166.5, $P<0.0001$, respectively). Males had significantly higher total and free cortisol concentrations than females $\left(F_{[1,52]}=111.0, P<0.0001\right.$, and $F_{[1,52]}=235.7, P<0.0001$, respectively) and both total and free cortisol concentrations showed significant interaction effects $\left(F_{[1,52]}=178.0, P<\right.$ 0.0001 , and $F_{[1,52]}=32.2, P<0.0001$, respectively). The interaction effect between sex and treatment was due to the fact that in females, total and free cortisol concentrations were 12 and 34 times higher, respectively, in livetrapped than in base-line animals, whereas in males, concentrations of both only increased approximately 3- to 4-fold. Concentrations in base-line males were initially much higher than those in base-line females (about 9 times for total cortisol and 51 times for free cortisol), and changed much less in males in response to trapping and handling than in females. Thus, livetrapping strongly activated the stress response in both male and female ground squirrels, but had no effect on the binding capacity of plasma for cortisol. Females had much lower total and free cortisol concentrations initially, but responded more dramatically to trapping stress than did males.

\section{Effect of reproduction on plasma cortisol concentration}

We limited our analysis of changes in cortisol concentration with reproductive status to the Bear Creek Flat population because it was studied most intensively and was relatively stable over time. Thus, we were confident of the precise reproductive and age status of each animal and had a reasonable number of blood samples from most of the reproductive classes. As we were interested in the general pattern of variation among age and reproductive classes, we pooled samples from the different years (1987-1990). Males and females were each grouped into three classes (males: juveniles, nonreproductive adults, and reproductive adults; females:

juveniles, lactating adults, and pregnant adults) and we used a one-way ANOVA to assess variation among the six classes in total cortisol and free cortisol concentrations and MCBC values. Blood samples were collected during the following periods: 20 April - 28 May for reproductive males, 11 May 12 July for nonreproductive males, 23 April - 20 May for pregnant females, 7-29 June for lactating females, and 8 June - 20 July for juvenile males and females. Though the sex ratio of juveniles was roughly equal on first entry into the live traps (Lacey 1991), we analyzed a smaller sample of juvenile females $(N=44)$ than of juvenile males $(N=290)$ because one of us (Lacey et al. 1997) needed to genotype all juvenile males, as these were potentially future fathers. Two adult female classes were excluded from the analysis, owing to small sample sizes (in late April - May, blood was collected from 3 females that may have been pregnant but were not known to have given birth; in late June-July, blood was collected from 4 post lactating adults).

Though a number of animals were bled twice, each animal was allowed to contribute only once to each reproductive class by randomly deleting other samples (by assigning random numbers and deleting the lowest one). We also assumed that for a given animal, each hormone concentration in a reproductive class was independent of the concentration while it was in another reproductive class. This was tested by examining the repeatability of hormone concentrations within all animals bled more than once, and in all cases there was no significant repeatability (because of marked differences between males and females, the sexes were analyzed separately; males: total cortisol concentration, $F_{[8,9]}=$ 1.64, $P=0.24$; $\mathrm{MCBC}$ value, $F_{[8,9]}=0.76, P=0.64$; free cortisol concentration, $F_{[8,9]}=1.83, P=0.19$; females: total cortisol concentration, $F_{[7,10]}=2.91, P=0.06$; $\mathrm{MCBC}$ value, $F_{[7,10]}=2.25, P=0.12$; free cortisol concentration, $F_{[7,10]}=$ $0.29, P=0.94)$. Thus, we were justified in including samples from the same animals that were bled while they were in different reproductive states.

There were significant differences among the sex and reproductive groups in total cortisol concentrations $\left(F_{[5,429]}=\right.$ 23.08, $P<0.0001)$, MCBC values $\left(F_{[5,429]}=132.18, P<\right.$ 
Fig. 2. Changes in plasma concentrations (mean $\pm \mathrm{SE}$ ) of total cortisol and free cortisol and maximum corticosteroid binding capacity $(\mathrm{MCBC})$ as a function of reproductive status in male and female arctic ground squirrels. Sample sizes for the categories are as follows: males: 267 juvenile, 23 nonreproductive, and 49 reproductive; females: 44 juvenile, 14 lactating, and 38 pregnant. The results of the statistical analysis are given in the text. Different letters above the bars indicate significant differences among means for each concentration; both sexes are included simultaneously within a comparison.
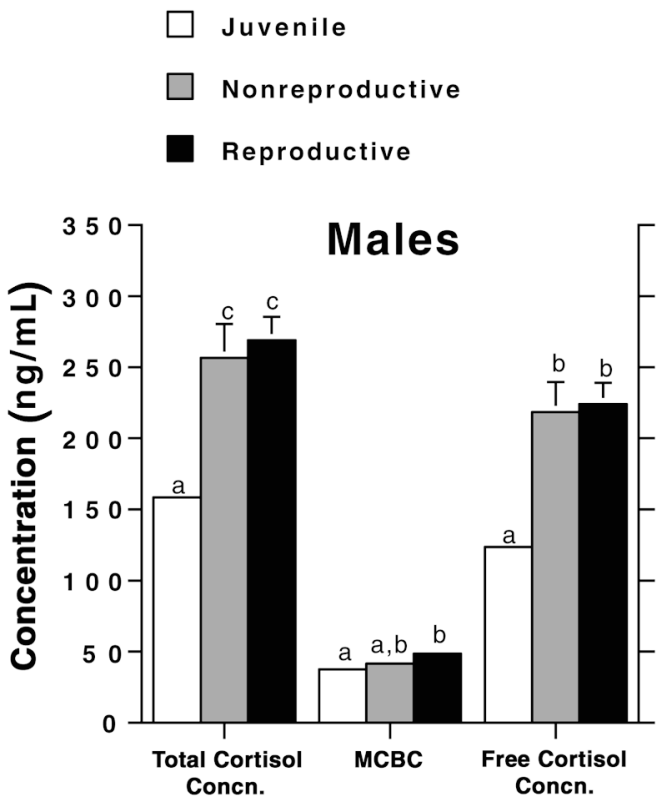

$0.0001)$, and free cortisol concentrations $\left(F_{[5,429]}=17.19\right.$, $P<0.0001)$ (Fig. 2). Though total cortisol concentrations tended to be similar and higher in adults than in juveniles, there were marked differences in free cortisol and MCBC values between the sexes and among age-classes. All female classes had lower free cortisol concentrations than the male classes, though this difference was significant only in comparison with adult males. All females had MCBC values 2-3 times those of males, and pregnant and lactating females had values approximately 2 or more times those of juvenile females. Thus, both sex and reproductive status had major effects on plasma cortisol concentrations and MCBC values.

\section{Testosterone concentrations in males}

We examined the effect of trapping and handling on testosterone concentrations in reproductive males by comparing samples obtained from base-line animals with those in animals obtained by livetrapping. There was no difference between samples from base-line animals collected in 1991 and 1995 ( $t=1.43,9 \mathrm{df}, P=0.18$ ), therefore years were pooled. Stress normally causes a decline in testosterone concentration in wild mammals (e.g., Sapolsky 1985; Boonstra and Singleton 1993); however, we observed the opposite relationship, with testosterone concentrations significantly lower in samples from base-line animals $(9.65 \pm 2.25 \mathrm{ng} / \mathrm{mL}, N=10)$ than in samples from trapped animals $(14.20 \pm 0.92 \mathrm{ng} / \mathrm{mL}$, $\left.N=48 ; F_{[1,56]}=6.6, P=0.01\right)$. Thus, trapping and handling increased, rather than decreased, testosterone concentrations.

Adult males were obviously reproductive only in April and May (dates on which the last males were detected as having scrotal testes ranged from 5 May 1987 to 28 May 1989; Lacey 1991). We examined variation in testosterone concentration in relation to breeding condition. We pooled samples from the different years (1987-1990), as we were interested in determining the general pattern of differences amongst age and reproductive classes. Three males had nonscrotal testes in April and were excluded from the analysis. All other overwintering males were reproductive in early spring (April - mid-May), but were nonreproductive (nonscrotal testes) in late spring and summer. Thus, the comparisons were among three classes: overwintering breeding males that were reproductive, overwintering males that were nonreproductive (but had been reproductive), and juveniles. We ensured that each male contributed only once to each class by randomly deleting other samples, and 8 males contributed to two classes. All classes differed significantly from each other $\left(F_{[2,328]}=\right.$ $391.7, P<0.0001)$, with juveniles having plasma testosterone concentrations 10 times lower than those of adult nonreproductive males and 16 times lower than those of adult reproductive males (Fig. 3). Nonreproductive adult males maintained high testosterone concentrations throughout the active season (about $64 \%$ of those of adult reproductive males).

We found no relationship between MCBC values and testosterone concentrations when all adult males (reproductive and nonreproductive) were pooled $(r=-0.08, P=0.53)$, but we did find a weak inverse relationship when we examined only nonreproductive males $(r=-0.27, P=0.06)$.

\section{Discussion}

We have demonstrated that arctic ground squirrels show a marked stress response to trapping and handling and that this response varied significantly between males and females (Fig. 1). At the height of the mating season in late April early May, breeding adult males had much higher (51 times) base-line free cortisol concentrations than breeding females, but a much more limited capacity to respond to trapping (concentrations in males increased only 4 times compared 
Fig. 3. Plasma testosterone concentrations (mean \pm SE) in male arctic ground squirrels from Bear Creek Flats, Yukon. Samples from adult reproductive males were obtained in April-May, from nonreproductive adult males in May-July, and from juvenile males in June and July. Numbers above the bars are sample sizes.

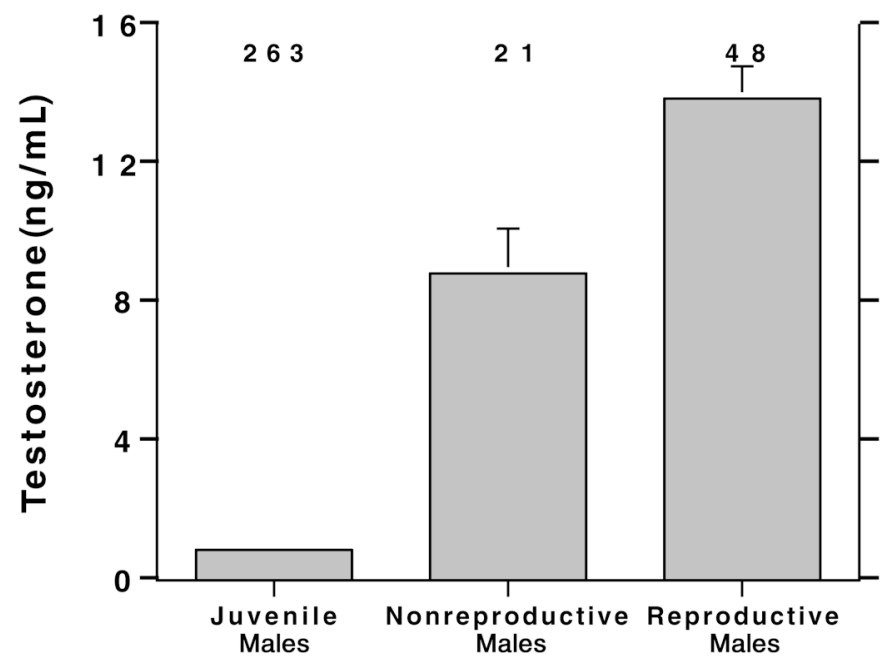

with 34 times in females) (Fig. 1). MCBC values in both sexes were unaffected by trapping. Testosterone concentrations were about $50 \%$ higher in livetrapped males than in base-line males. MCBC values and free cortisol concentrations varied significantly with reproductive condition, those in breeding females (pregnant or lactating) being the highest. These MCBC values buffered the females against the higher total cortisol concentrations, resulting in free cortisol concentrations that were similar in all female classes (including juveniles) and significantly lower than those in adult males (Fig. 2). Adult males, whether they were reproductive (scrotal testes) or not (after reproduction), maintained much higher testosterone concentrations throughout the active season (Fig. 3), and also significantly higher free cortisol concentrations (Fig. 2), than juvenile males and all female classes.

We will discuss three caveats before interpreting the data. First, there is disagreement as to the identity of the principal glucocorticoid in sciurids, but we propose that the evidence is consistent with the conclusion that both corticosterone and cortisol are produced, but that cortisol is the primary one. Part of the reason for the lack of consensus may be that in most of the early studies, the methods used were not as accurate or as precise as RIA (e.g., Adams (1972) used TLC, Huibregtse et al. (1971) used both TLC and fluorometric measurement, Vanjonack et al. (1975) used competitive protein binding, and Armitage (1991) used fluorometric measurement). In addition, in some studies it was assumed that only cortisol was present (Florant and Weitzman 1980 (woodchuck, Marmota monax); Shivatcheva et al. 1988 (the European ground squirrel Spermophilus citellus)). In an in vitro study on adrenal glands from California ground squirrels (Spermophilus beecheyi), both shot and previously stimulated with ACTH, Adams (1972) found that though both glucocorticoids were produced, cortisol was the principal one, and that only cortisol responded dramatically to ACTH. In Armitage's (1991) study on the yellow-bellied marmot (Marmota flaviventris), in which the corticosteroid was not identified, there was no effect of either age or reproductive condition on corticosteroid concentrations in blood samples taken from free-living animals (livetrapped and bled from the femoral vein). Given the marked effects of both sex and reproductive condition in mammals that both we and others have found (Figs. 1 and 2), we suggest that the animals were indeed stressed by the trapping procedure, but that the fluorometric method which was used measured primarily corticosterone, not cortisol, and that the former did not respond to the differences between the sexes or among reproductive classes. Kastner et al. (1977), who also worked on M. flaviventris, surgically stressed them, collected venous blood flowing directly from the adrenals, and analyzed it for both corticosterone and cortisol with RIA. They found that the secretion rate was $15.2 \mathrm{ng} / \mathrm{min}$ for corticosterone and $554 \mathrm{ng} / \mathrm{min}$ for cortisol. In a study of seasonal changes in hormone concentrations in field-caught golden-mantled ground squirrels (Spermophilus saturatus), most of which were accustomed to capture and handling, Boswell et al. (1994) found (using RIA) that both glucocorticoids were present, with cortisol concentrations about 2-3 times corticosterone concentrations. These concentrations must represent those from animals stressed by the livetrapping protocol. In the yellow-pine chipmunk (Tamias amoenus), Kenagy and Place (2000) and Place and Kenagy (2000) found both steroids present in livetrapped animals, with cortisol concentrations about 10 times corticosterone concentrations. Finally, our initial analysis in arctic ground squirrels clearly indicated that cortisol was the primary glucocorticoid present, and corticosterone was unmeasurable in most animals $(67 \%)$, and that cortisol concentrations were strongly affected by trapping and handling (Fig. 1). Thus, though corticosterone may be secreted, the more potent cortisol is the dominant glucocorticoid. We recommend that in all future studies on the stress physiology of sciurids, cortisol be measured.

The second caveat concerns the issue of whether the stress of livetrapping and handling (Fig. 1) obscured the seasonal pattern of changes in cortisol and testosterone concentrations (Figs. 2 and 3). We think that this is unlikely for two reasons. First, as indicated in the Methods for the Bear Creek Flats population, the time between capture and bleeding was short (usually less than $20 \mathrm{~min}$ ) and thus the bias, if any, was relatively constant. Second, Kenagy and Place (2000) and Place and Kenagy (2000), who assessed the impact of trapping and handling stress in the yellow-pine chipmunk, using a novel protocol in which the animals were bled immediately on capture and again 30 min later, concluded that standard trapping procedures did not obscure the natural pattern of seasonal changes in either glucocorticoid or testosterone concentration.

The third caveat concerns the issue of whether the ground squirrels' response to livetrapping remained constant over the season (i.e., there was indeed a stress-induced response to the trapping protocol in early spring (Fig. 1), but since we did not obtain base-line concentrations at other times, we cannot be sure whether the ground squirrels were stressed to the same degree or not at all later in the season). Some bird species, or even different populations within the same species, living in areas with severe, unpredictable weather, such as the Arctic, are hypo-responsive to these weather events and this may be an adaptation to permit reproduction (e.g., 
Silverin et al. 1997; Wingfield et al. 1997). We cannot be sure that the squirrels' sensitivity to the trapping protocol varied over the season. However, we do know that at no time were they hypo-responsive to a standardized hormonal challenge consisting of a dexamethasone-suppression test followed by an ACTH-stimulation test (for a general description of this protocol see Boonstra and McColl 2000). We have tested ground squirrels (males and females, adults and juveniles) in June, July, and August with this challenge protocol (McColl 1998; R. Boonstra and C.J. McColl, unpublished data), and at all times cortisol concentrations were suppressed by dexamethasone and stimulated by ACTH.

\section{Changes in glucocorticoid concentration}

We found that neither male nor female ground squirrels showed significant changes in MCBC values, relative to baseline animals, in response to the stress of capture (Fig. 1), and this was expected. Though the CBG concentration (our measure of this was the MCBC value) is known to show longterm (after $24 \mathrm{~h}$ or more) declines in response to stressors (Dallman et al. 1990; Armario et al. 1994; Fleshner et al. 1995), it is thought to have little capacity to make rapid short-term changes (except in lagomorphs; Boonstra and Singleton 1993; Boonstra et al. 1998; Boonstra and Tinnikov 1998). However, Boonstra and McColl (2000) found small but significant declines in MCBC values following a 4-h hormonal challenge in both male arctic ground squirrels (by 4\%) and male red squirrels (Tamiasciurus hudsonicus) (by $12 \%$ ). The critical component in the stress response of mammals is the serum CBG concentration. The bioavailability of circulating corticosteroids for target tissues is mediated by $\mathrm{CBG}$, which acts as the carrier protein for cortisol. When bound to CBG, cortisol is biologically inactive (Rosner 1990) and, under basal conditions, 90-95\% of plasma glucocorticoids are bound to CBG. All other studies done on sciurids (except for that of Armitage 1991) have measured only total corticosteroids and these are a poor reflection of what is actually available to tissues. For example, total cortisol concentrations in pregnant and lactating females were significantly higher than in juvenile females, but free cortisol concentrations did not vary among the three groups because of the high MCBC values in the former two groups (Fig. 2). Kenagy and Place (2000) found that lactating female yellow-pine chipmunks had significantly higher total cortisol concentrations than pregnant and mating females or post-lactation females. However, given that the CBG concentration increases markedly with pregnancy and lactation in rodents (e.g., Rosenthal et al. 1969a, 1969b; Westphal 1971; McDonald et al. 1988; Boonstra and Boag 1992; Fig. 2), lactating chipmunks may be well buffered from these high concentrations. The same problem of interpretation arises in the study of Place and Kenagy (2000) on male yellow-pine chipmunks. They report low concentrations of both cortisol and corticosterone during the mating season, but given that $\mathrm{CBG}$ levels were not known, free cortisol and corticosterone levels may be high if $\mathrm{CBG}$ levels are low, as we have found here and was reported in Boonstra et al. (2001). Thus, in response to a stressor such as livetrapping, the rapid release of cortisol may result in a major pulse of free cortisol if the binding capacity of $\mathrm{CBG}$ is swamped (Westphal 1971; Dallman et al. 1989), but not if the animal is buffered by high $\mathrm{CBG}$ concentrations, as preg- nant and lactating rodents are. Thus, to understand the dynamics of corticosteroids, both total and free concentrations should be measured.

Total cortisol concentrations vary markedly among the various species of the squirrel subfamily Sciurinae (family Sciuridae; Hafner 1984), but the reason is not obvious. Low total cortisol concentrations have been found in three species. In nonhibernating woodchucks, Florant and Weitzmann (1980), using chronically implanted catheters for sampling blood without disturbing the animals, found cortisol concentrations from 4 to $12 \mathrm{ng} / \mathrm{mL}$. In yellow-bellied marmots (both sexes pooled, from all seasons), Kastner et al. (1977) reported an average cortisol concentration of $54 \mathrm{ng} / \mathrm{mL}$, but the stress level experienced by these animals at the time of bleeding (cardiac puncture or implanted catheter) is unclear. In golden-mantled ground squirrels (Spermophilus lateralis) Boswell et al. (1994), using livetrapped animals that must have been stressed by trapping and handling, found cortisol concentrations of 10-27 ng/mL in adult females (pregnant, lactating, or postlactating) and $13-26 \mathrm{ng} / \mathrm{mL}$ in adult males (breeding or nonreproductive). In contrast, in arctic ground squirrels (our study), total cortisol concentrations were about 10 times those in the above three species $(158-269 \mathrm{ng} / \mathrm{mL}$ for males, over all classes; $174-307 \mathrm{ng} / \mathrm{mL}$ for females, over all classes; Fig. 1 and 2). In red squirrels, Boonstra and McColl (2000), using breeding males stressed by handling, found a base-line concentration of $736 \mathrm{ng} / \mathrm{mL}$, which is about 35 times those in the above first three species. Finally, in the yellow-pine chipmunk, Kenagy and Place (2000), using females from a livetrapping study, found cortisol concentrations of $906-1686 \mathrm{ng} / \mathrm{mL}$ which are about 50 times those found in the above first three species. Place and Kenagy (2000) report similar levels in male yellow-pine chipmunks. It is not at all clear what ecological forces could select for this enormous range in cortisol concentration, as the first four species are all members of the same tribe (Marmotina, burrowing squirrels; Hafner 1984), they have similar life histories, and all hibernate. The fifth species is a member of the subtribe Sciurni (tree squirrels) and the sixth is a member of the Tamiini (chipmunks). Red squirrels and chipmunks tend to be much more active than the other species, but activity levels cannot be the sole explanation, as the two Spermophilus species do not appear to differ markedly in activity level (R. Boonstra, personal observation), but differ by an order of magnitude in cortisol concentration. Thus, the cause of the large range in cortisol concentrations remains an enigma.

\section{Changes in testosterone concentration}

In mammals, stressors can suppress testosterone production (Sapolsky 1992). This effect has been found in two marsupial species (Antechinus swainsonii (McDonald et al. 1986) and Phascogale calura (Bradley 1990)), baboons (Papio anubis (Sapolsky 1985)), snowshoe hares (Lepus americanus (Boonstra and Singleton 1993)), and red squirrels (Boonstra and McColl 2000). However, in ground squirrels the stress associated with trapping and handling had the opposite effect, increasing the testosterone concentration. This result was not just an anomalous one caused by low sample size. Using an hormonal challenge protocol, Boonstra and McColl (2000) found that testosterone concentrations increased in breeding males within $30 \mathrm{~min}$ and for up to $2 \mathrm{~h}$ after an ACTH injection. 
Boonstra et al. (2001) found the same for both juveniles and nonreproductive males in August. The response of breeding males to stress may be similar to that of high-ranking male baboons, which show a transient increase in testosterone during the first post stress hour (Sapolsky 1985), whereas concentrations in subordinate males begin to decline immediately (within $30 \mathrm{~min}$ ) and continuously following exposure to a stressor. Similar responses have been seen in snowshoe hares in good condition (Boonstra and Singleton 1993; Boonstra et al. 1998). However, in male arctic ground squirrels this rise in testosterone concentration when the animals are stressed seems to be a more generalized trait and is probably not restricted to males in good condition nor to dominant ones. Place and Kenagy (2000) found a similar rise in testosterone levels with trapping and handling stress in the yellow-pine chipmunk in the breeding season but not at other times. Boonstra and McColl (2000) postulate that this is an evolutionary adaptation of arctic ground squirrels associated with competition for access to females during the short, intense yearly mating season.

Though high testosterone concentrations in other species are associated with reduced $\mathrm{CBG}$ concentrations, we found no evidence of this in arctic ground squirrels. Adult males, whether they were reproductively active or not, had high testosterone concentrations. In male Antechinus spp. (Bradley et al. 1980; McDonald et al. 1981), increasing the testosterone concentration caused CBG concentrations to fall, and failure of the pituitary-adrenocortical feedback system (McDonald et al. 1986) caused free corticosteroid concentrations to rise when aggressive breeding interactions occurred. The net result was a collapse of the immune and inflammatory responses and total male mortality after a brief mating period. Male Australian bush rats (Rattus fuscipes) also showed an inverse relationship between testosterone concentration and CBG concentration and associated breeding-related mortality (McDonald et al. 1988). In contrast, no relationship was found between testosterone concentration and CBG concentration in Microtus pennsylvanicus (Boonstra and Boag 1992), Townsend's vole (Microtus townsendii) (McDonald and Taitt 1982), or another dasyurid marsupial, Sminthopsis crassicaudata (McDonald et al. 1981). In the first group of species the inverse relationship between testosterone and $\mathrm{CBG}$ concentrations appears to be associated with breeding-related mortality due to stress symptoms; in the second group of species, in which no inverse relationship occurs, the animals may disappear for other reasons (e.g., death due to predation or loss by dispersal). It is not clear where the arctic ground squirrel sits in this continuum. A major unknown factor is the cause of the disappearance of males at the end of the mating period. Boonstra et al. (2001) report a loss of over $40 \%$ of males immediately following the mating period. They found that breeding males appeared to be suffering from the effects of chronic stress, with severely reduced immune function, whereas at other times males were in much better condition.

For adult males that do survive into summer, it is not immediately obvious why testosterone concentrations remain high through the nonreproductive period and into June and early July (our last sample was caught in mid-July) (Fig. 3). One possible explanation is the need for adult breeding males to maintain vigilance and exhibit aggressive behaviour around the burrowing sites of the females with which they have mated to protect the young from infanticidal yearling males (McLean 1983; Lacey 1991). The typical pattern for juvenile males is to disperse from the natal burrow in the summer of their birth, probably to avoid mating with close relatives the next spring (Holekamp and Sherman 1989; Lacey 1991). However, Lacey (1991) found that a number of juvenile males do not disperse from their natal area in their year of birth (apparently because of low body mass), do not participate in reproduction the next spring, and only disperse from their natal site after the mating period is finished and when the females are rearing their next litter. These young males apparently attempt to take over the burrow systems of unrelated adult females and in the process kill the young of these females (Lacey 1991). Lacey (1991) proposed that adult breeding males should not disperse until after their young have emerged, in order to protect their progeny from these infanticidal males. Holekamp and Talamantes (1992) monitored seasonal changes in testosterone concentration and behaviour in California ground squirrels and found that, in contrast to our results, testosterone dropped to low concentrations within 2 weeks of the mating season, and associated with this was a sharp decline in agonistic behaviour. Young males of this species do not breed until they are 2 years old (virtually all arctic ground squirrels breed as yearlings, except for the stay-at-home low-body-mass males); $90 \%$ disperse in their first year, and all have done so by 55 weeks of age (Holekamp 1984). The risk of infanticidal behaviour by yearlings may be much lower or absent in California ground squirrels than in arctic ground squirrels, hence there is no need for high testosterone concentrations in adult male California ground squirrels well after the breeding season is finished.

In conclusion, arctic ground squirrels are markedly affected by the stress of capture and handling, but during the mating period reproductive adult males already have high free cortisol concentrations independently of the effects of this stressor and are less capable of mounting a stress response than females. In contrast, adult females show a major response to trapping stress, but during the period of lactating and pregnancy, they are buffered from the effects of high free cortisol concentrations by high MCBC. Testosterone concentrations in adult males increase in response to trapping stress and remain high even when they are not breeding.

\section{Acknowledgments}

We thank L. Lu for assisting with the RIA assays. We thank the Natural Sciences and Engineering Research Council of Canada for providing funds to R.B., A.H., and C.M. We thank the Arctic Institute of North America, University of Calgary, for use of the facilities at the Kluane Lake Base. Permission to conduct fieldwork at Bear Creek Flats was given by the Heritage Branch, Yukon Territorial Government, by the Department of Renewable Resources, and by the Champagne-Aishihik Band. Financial support for this work was provided by a National Science Foundation Predoctoral Fellowship awarded to E.A.L. and by research grants from the American Museum of Natural History, Sigma Xi, the American Society of Mammalogists, and the Museum of Zoology, Department of Biology, and Rackham School of 
Graduate Studies at the University of Michigan. This is contribution No. 111 of the Kluane Boreal Forest Ecosystem Project.

\section{References}

Adams, L. 1972. Evaluation of an in vitro technique for quantitative assay of adrenocortical secretion in the California ground squirrel. J. Wildl. Manag. 8: 10-18.

Armario, A., Giralt, M., Marti, O., Guvalda, A., Hidalgo, J., Hsu, B.R-S., and Kuhn, R.W. 1994. The effect of acute and chronic ACTH administration on pituitary-adrenal response to acute immobilization stress: relationship to changes in corticosteroidbinding globulin. Endocrinol. Res. 20: 139-149.

Armitage, K.B. 1991. Factors affecting corticosteroid concentrations in yellow-bellied marmots. Comp. Biochem. Physiol. A, 98: 47-54.

Boonstra, R., and Boag, P.T. 1992. Spring declines in Microtus pennsylvanicus and the role of steroid hormones. J. Anim. Ecol. 61: $339-352$.

Boonstra, R., and McColl, C.J. 2000. Contrasting stress response of male arctic ground squirrels and red squirrels. J. Exp. Zool. 268: 390-404.

Boonstra, R., and Singleton, G.R. 1993. Population declines in the snowshoe hare and the role of stress. Gen. Comp. Endocrinol. 91: 126-143.

Boonstra, R., and Tinnikov, A.A. 1998. Increased corticosteroid binding capacity of plasma albumin but not of CBG caused by ACTH induced changes in free fatty acid concentrations in snowshoe hares and rabbits. J. Endocrinol. 156: 205-212.

Boonstra, R., Hik, D., Singleton, G.R., and Tinnikov, A. 1998. The impact of predator-induced stress on the snowshoe hare cycle. Ecol. Monogr. 68: 371-394.

Boonstra, R., McColl, C.J., and Karels, T.J. 2001. Reproduction at all costs: how breeding compromises the stress response and survival in male Arctic ground squirrels. Ecology. 82. In press.

Boswell, T., Woods, S.C., and Kenagy, G.J. 1994. Seasonal changes in body mass, insulin, glucocorticoids of free-living golden-mantled ground squirrels. Gen. Comp. Endocrinol. 96: 339-346.

Boutin, S., Krebs, C.J., Boonstra, R., Dale, M.R.T., Hannon, S.J., Martin, K., Sinclair, A.R.E., Smith, J.N.M., Turkington, R., Blower, M., Byrom, A., Doyle, F.I., Doyle, C., Hik, D., Hofer, L., Hubbs, A., Karels, T., Murray, D.L., Nams, V., O’Donoghue, M., Rohner, C., and Schweiger, S. 1995. Population changes of the vertebrate community during a snowshoe hare cycle in Canada's boreal forest. Oikos, 74: 69-80

Bradley, A. 1987. Stress and mortality in the red-tailed Phascogale Phascogale calura (Marsupialia: Dasyuridae). Gen. Comp. Endocrinol. 67: 85-100.

Bradley, A. 1990. Failure of glucocorticoid feedback during breeding in the male red-tailed phascogale Phascogale calura (Marsupialia: Dasyuridae). J. Steroid Biochem. Mol. Biol. 37: 155-163.

Bradley, A.J., McDonald, I.R., and Lee, A.K. 1980. Stress and mortality in a small mammal (Antechinus stuartii MacLeay). Gen. Comp. Endocrinol. 40: 188-200.

Byrom, A.E., and Krebs, C.J. 1999. Natal dispersal of juvenile arctic ground squirrels in the boreal forest. Can. J. Zool. 77: 1048-1059.

Byrom, A.E., Karels, T., Krebs, C.J., and Boonstra, R. 2000. Experimental manipulation of predation and food for arctic ground squirrels in the boreal forest. Can. J. Zool. 78: 1309-1319.

Challis, J.R., Kendall, J.Z., Robinson, J.S., and Thorburn, G.D. 1977. The regulation of corticosteroids during late pregnancy and their role in parturition. Biol. Reprod. 16: 57-69.
Croze, F., and Etches, R.J. 1980. The physiological significance of androgen-induced ovulation in the hen. J. Endocrinol. 84: 163-171.

Crump, C.J., and Chevins, P.F. 1989. Prenatal stress reduces fertility of male offspring in mice, without affecting their adult testosterone levels. Horm. Behav. 23: 333-343.

Dahlof, L.-G., Hard, E., and Larsson, K. 1977. Influence of maternal stress on offspring sexual behavior. Anim. Behav. 25: 958-963.

Dallman, M.F., Darlington, D.N., Suemaru, S., Cascio, C.S., and Levin, N. 1989. Corticosteroids in homeostasis. Acta Physiol. Scand. 136(Suppl. 583): 27-34.

Dallman, M.F., Akana, S.F., Cascio, C.S., Darlington, D.N., Jacobson, L., and Levin, N. 1990. Regulation of ACTH secretion: variations on a theme of B. Recent Prog. Horm. Res. 43: 113-173.

Day, R.W., and Quinn, G.P. 1989. Comparisons of treatment after an analysis of variance in ecology. Ecol. Monogr. 59: 433-463.

Fleshner M., Deak, T., Spencer, R.L., Laudenslager, M.L., Watkins, L.R., and Maier, S.F. 1995. A long term increase in basal levels of corticosterone and a decrease in corticosteroid-binding globulin after acute stressor exposure. Endocrinology, 136: 5336-5342.

Florant, G.L., and Weitzman, E.D. 1980. Diurnal and episodic pattern of plasma cortisol during fall and spring in young and old woodchucks (Marmota monax). Comp. Biochem. Physiol. A, 66: $575-581$.

Gagnon, J., Roth, J., Finzer, B., Hofmann, R., Haycock, K., Simpson, J., and Feldman, D. 1991. SuperANOVA: Accessible General Linear Modelling. Abacus Concepts, Inc., Berkeley, Calif.

Hafner, D.J. 1984. Evolutionary relationships of the Nearctic Sciuridae. In The biology of ground-dwelling squirrels. Edited by J.O. Murrie and G.R. Michener. University of Nebraska Press, Lincoln. pp. 1-23.

Herrenkohl, L.R. 1979. Prenatal stress reduces fertility and fecundity in female offspring. Science (Washington, D.C.), 206: 1079-1099.

Holekamp, K.E. 1984. Natal dispersal in Belding's ground squirrels (Spermophilus beldingi). Behav. Ecol. Sociobiol. 16: 21-30.

Holekamp, K.E., and Sherman, P.W. 1989. Why male ground squirrels disperse. Am. Sci. 77: 232-239.

Holekamp, K.E., and Talamantes, F. 1992. Seasonal fluctuations in hormones and behavior of free-living male California ground squirrels (Spermophilus beldingi). Horm. Behav. 26: 7-23.

Hubbs, A.H., and Boonstra, R. 1997. Population limitation in Arctic ground squirrels: effects of food and predation. J. Anim. Ecol. 66: 527-541.

Huibregtse, W.H., Gunville, R., and Unger, F. 1971. Secretion of corticosterone in vitro by normothermic and hibernating ground squirrels. Comp. Biochem, Physiol. A, 38: 763-768.

Karels, T.J., Byrom, A., Boonstra, R., and Kreb, C.J. 2000. The interactive effects of food and predators on reproduction and overwinter survival of Arctic ground squirrels. J. Anim. Ecol. 69: 235-247.

Kastner, P.R., Zatzman, M.L., South, F.E., and Johnson, J.A. 1977. Renin-angiotensin-aldosterone system of the normothermic marmot. Am. J. Physiol. 135: R37-R43.

Kenagy, G.J., and Place, N.J. 2000. Seasonal changes in plasma glucocorticoids of free-living yellow-pine chipmunks: effects of reproduction and capture and handling. Gen. Comp. Endocrinol. 117: 189-199.

Krebs, C.J., Boutin, S., Boonstra, R., Sinclair, A.R.E., Smith, J.N.M, Dale, M.R.T., Martin, K., and Turkington, R. 1995. Impact of food and predation on the snowshoe hare cycle. Science (Washington, D.C.), 269: 1112-1115.

Lacey, E.A. 1991. Reproductive and dispersal strategies of male Arctic ground squirrels (Spermophilus parryii plesius). Ph.D. thesis, University of Michigan, Ann Arbor. 
Lacey, E.A., Wieczorek, J.R., and Tucker, P.K. 1997. Male mating behaviour and patterns of sperm precedence in Arctic ground squirrels. Anim. Behav. 53: 767-779.

Lee, A.K., and Cockburn, A. 1985. Evolutionary ecology of marsupials. Cambridge University Press, Cambridge.

Liggins, G.C. 1982. The fetus and birth. In Embryonic and fetal development. Edited by C.R. Austin and R.V. Short. Cambridge University Press, London. pp. 114-141.

Martin, C.E., Cake, M.H., Hartmann, P.E., and Cook, I.F. 1977. Relationship between foetal corticosteroids, maternal progesterone, and parturition in the rat. Acta Endocrinol. 84: 167-176.

McColl, C.J. 1998. The role of food, predation, and population density on the stress physiology of Arctic ground squirrels. M.Sc. thesis, University of Toronto, Toronto, Ont.

McDonald, I.R., and Taitt, M.J. 1982. Steroid hormones in the blood plasma of Townsend's vole (Microtus townsendii). Can. J. Zool. 60: 2264-2269.

McDonald, I.R., Lee, A.K., Bradley, A.J., and Than, K.A. 1981. Endocrine changes in dasyurid marsupials with differing mortality patterns. Gen. Comp. Endocrinol. 44: 292-301.

McDonald, I.R., Lee, A.K., Than, K.A., and Martin, R.W. 1986. Failure of glucocorticoid feedback in males of a population of small marsupials (Antechinus swainsonii) during a period of mating. J. Endocrinol. 108: 63-68.

McDonald, I.R., Lee, A.K., Than, K.A., and Martin, R.W. 1988. Concentrations of free glucocorticoids in plasma and mortality in the Australian bush rat (Rattus fuscipes Waterhouse). J. Mammal. 69: 740-748.

McEwen, B.S., Brinton, R.W., and Sapolsky, R.M. 1988. Glucocorticoid receptors and behavior: implications for the stress response. Adv. Exp. Med. Biol. 245: 35-45

McLean, I.G. 1981. Social ecology of the Arctic ground squirrel Spermophilus parryii. Ph.D. thesis, University of Alberta, Edmonton, Alta.

McLean, I.G. 1983. Paternal behaviour and killing of young in Arctic ground squirrels. Anim. Behav. 31: 32-44.

Michener, G.R., and Locklear, L. 1990. Differential costs of reproductive effort for male and female Richardson's ground squirrels. Ecology, 71: 855-868.

Morton, M.L., and Sherman, P.W. 1978. Effects of a spring snowstorm on behavior, reproduction and survival of Belding's ground squirrels. Can. J. Zool. 56: 2578-2590.

Munck, A., Guyre, P., and Holbrook, N. 1984. Physiological functions of glucocorticoids during stress and their relation to pharmacological actions. Endocr. Rev. 5: 25-44.
Place, N.J., and Kenagy, G.J. 2000. Seasonal changes in plasma testosterone and glucocorticosteroids in free-living male yellowpine chipmunks and the response to capture and handling. J. Comp. Physiol. B, 170:2 45-251.

Rosenthal, H.E., Slaunwhite, W.R., Jr., and Sandberg, A.A. $1969 a$. Transcortin: a corticosteroid-binding protein in plasma. X. Cortisol and progesterone interplay and unbound levels of these steroids in pregnancy. J. Clin. Endocrinol. Metab. 29: 352-367.

Rosenthal, H.E., Slaunwhite, W.R., Jr., and Sandberg, A.A. $1969 b$. Transcortin: a corticosteroid-binding protein in plasma. XI. Effects of estrogens and pregnancy in guinea pigs. Endocrinology, 85: $825-830$.

Rosner, W. 1990. The functions of corticosteroid-binding globulin and sex hormone-binding globulin: recent advances. Endocr. Rev. 11: $80-91$.

Sachser, N., and Kaiser, L. 1996. Prenatal social stress masculinizes the females' behavior in guinea pigs. Physiol. Behav. 60: 589-594.

Sapolsky, R. 1985. Stress induced suppression of testicular function in the wild baboon: role of glucocorticoids. Endocrinology, 116: $2273-2278$.

Sapolsky, R. 1992. Neuroendocrinology of the stress-response. In Behavioral endocrinology. Edited by J.B. Becker, S.M. Breedlove, and D. Crews. MIT Press, Cambridge, Mass. pp. 287-324.

Shivatcheva, T.A., Ankov, V.K., and Hadjioloff, A.I. 1988. Circannual fluctuations of the serum cortisol in European ground squirrel, Citellus citellus L. Comp. Biochem. Physiol. A, 90: 515-518.

Silverin, B., Arvidsson, B., and Wingfield, J. 1997. The adrenocortical responses to stress in breeding Willow Warblers, Phylloscopus trochilus, in Sweden: effects of latitude and gender. J. Anim. Ecol. 11: 376-384.

Tan, S.T., and Mulrow, P.J. 1975. A competitive protein binding radioassay for deoxycorticosterone in human plasma. Steroids, 25: $1-13$.

Vanjonack, W.J., Scott, I.M., Yousef, M.K., and Johnson, H.D. 1975. Corticosterone plasma levels in desert rodents. Comp. Biochem. Physiol. A, 51: 17-20.

Westphal, U. 1971. Steroid-protein interactions. Monogr. Endocrinol. 4: $1-567$.

Wingfield, J.C., Breuner, C., and Jacobs, J. 1997. Corticosterone and behavioral responses to unpredictable events. In Perspectives in avian endocrinology. Edited by S. Harvey and R.J. Etches. Journal of Endocrinology, Bristol. pp. 267-278.

Winer, B.J. 1971. Statistical principles in experimental design. 2nd ed. McGraw-Hill, New York. 